\title{
AKURASI OXYGEN SATURATION (SPO2) SEBAGAI PREDIKTOR MORTALITY PADA KLIEN CEDERA KEPALA
}

\author{
Riki Ristanto', Amin Zakaria \\ Program Studi Keperawatan Poltekkes RS. Dr. Soepraoen Malang \\ Jl. Sudanco Supriadi 22 Malang \\ E-mail : rikiristanto1983@gmail.com
}

\begin{abstract}
Cerebral hypoxia is secondary injury which affects the mortality of clients with Trauma Brain Injury (TBI). One component of respiration that can be used to monitor the occurrence of cerebral hypoxia is oxygen saturation (SpO2). The purpose of this study was to analyze the accuracy of oxygen saturation as a predictor of mortality in head injury clients. This study is an analytic observational with retrospective cohort design. The population is all head injury medical records from January to December 2017 at the hospital. dr. Iskak Tulungagung. A total of 150 samples were selected according to inclusion and exclusion criteria. The dependent variable in this study was the mortality of the head injury client in seven days of treatment and the independent variable was the value of SpO2 in the ED triage data in the client's medical record. The results of the Mann-Whitney test analysis showed that the SpO2 variable had a significant relationship with the mortality of the head injury client ( $p$ value $=0.000$ ). Logistic regression test shows that the $\mathrm{SpO} 2$ has sensitivity $=$ 0.907 (90.7\%), specificity $=0.881$ (88.1\%), Positive Predictive Value $(P P V)=0.951$ (95.1\%), and Negative Predictive Value $(N P V)=0.787(78.7 \%)$ with predictive accuracy capability $=90 \%$. Oxygen Saturation is an accurate predictor (90\% accuracy) of the mortality of the head injury client
\end{abstract}

Keywords : Mortality, Client Head Injury, Accuracy, Oxygen Saturation.

Abstrak : Hipoksia cerebral adalah secondary injury yang berdampak pada mortality klien dengan Trauma Brain Injury (TBI). Salah satu komponen respirasi yang dapat digunakan untuk memantau terjadinya Hipoksia cerebral adalah oxygen saturation (SpO2). Tujuan penelitian ini adalah untuk menganalisis akurasi oxygen saturation sebagai prediktor mortality pada klien cedera kepala. Penelitian ini adalah observasional analitik dengan desain cohort retrospektif. Populasinya adalah semua data rekam medis klien cedera kepala periode Januari hingga Desember 2017 di RS. dr. Iskak Tulungagung. Sejumlah 150 sampel dipilih sesuai dengan kriteria inklusi dan eksklusi. Variabel dependent dalam penelitian ini adalah mortality klien cedera kepala dalam tujuh hari perawatan dan variabel independentnya adalah nilai $\mathrm{SpO}_{2}$ pada data triage IGD. Hasil analisis Uji Mann-Whitney, menunjukkan bahwa variable $\mathrm{SpO} 2$ memiliki hubungan yang bermakna dengan mortality klien cedera kepala $(p$ value $=0.000$ ). Uji regresi logistik menunjukkan bahwa persamaan SpO2 memiliki sensitivity $=0.907(90.7 \%)$, specificity $=0.881(88.1 \%)$, Positive Predictive Value $(\mathrm{PPV})=0.951(95.1 \%)$, dan Negative Predictive Value (NPV) $=0.787(78.7 \%)$ dengan kemampuan ketepatan prediksi $=90 \%$. Oxygen Saturation (SpO2) merupakan prediktor yang akurat (akurasi 90\%) terhadap mortality klien cedera kepala.

Kata Kunci : Mortality, Klien Cedera Kepala, Akurasi, Oxygen Saturation.

\section{PENDAHULUAN}

Cedera kepala merupakan gangguan traumatik fungsi otak dan menjadi salah satu penyebab utama kematian dan kecacatan akibat trauma (Levine \& Kumar, 2013; Muttaqin, 2008; Tjahjadi et al., 2013). Kematian klien cedera kepala disebabkan salah satunya oleh adanya hipoksia cerebral yang tidak tertangani (Madikian, 2006; Minardi \& Crocco, 2009; Safrizal \& Bachtiar, 2013). Menurut Davis et al. (2009), pasien cedera kepala didapatkan awalnya sudah menderita Hipoksia sebanyak $30 \%$. Hipoksia merupakan secundar injury yang dapat meninggkatkan resiko mortality sebesar $22.4 \%$ (Brain Trauma Foundation, 2007; Bouzat et al., 2015). Hipoksia pada klien cedera kepala dapat terjadi karena berbagai sebab, diantaranya adalah apnea yang tiba-tiba atau karena pola pernafasan abnormal lainnya, adanya hipoventilasi akibat cedera sumsum tulang belakang, adanya obstruksi jalan nafas karena cedera kepala atau cedera leher, adanya cedera langsung pada dinding dada atau paru, dan adanya emboli lemak di sirkulasi pulmonal karena fraktur tulang panjang (Rosyidi \& Nurhidayat, 2009; Sastrodiningrat, 2006). Walaupun kejadian hipoksia cerebral cukup sering, namun monitoring fungsi respirasi jarang dilakukan sehingga banyak klien cedera kepala mengalami perburukan outcome atau bahkan kematian. Salah satu variable pernafasan yang dapat digunakan untuk 
memonitoring adanya proses hipoksia adalah oxygen saturation (SpO2) (Djojodibroto, 2007; Wilensky et al.,2009). Menurut McMulan et al. (2013), kondisi hipoksia dapat diketahui ketika hasil pengukuran Perifer Oxygen saturation $<90 \%$. Oxygen saturation merupakan salah satu indikator penentu yang utama pada suplai oksigen dalam darah ke seluruh jaringan tubuh. Maka pencegahan perburukan outcome klien cedera kepala akibat hipoksia cerebral dapat dilakukan dengan memantau langsung kadar oxygen saturation (SpO2). Tujuan penelitian ini adalah untuk menganalisis akurasi oxygen saturation sebagai prediktor mortality pada klien cedera kepala.

\section{METODE PENELITIAN}

Penelitian ini adalah observasional analitik dengan design cohort retrospektif. Populasinya adalah semua data rekam medis klien cedera kepala periode Januari hingga Desember 2017 di RS. dr. Iskak Tulungagung.
Sejumlah 150 sampel dipilih sesuai dengan kriteria inklusi dan eksklusi dari populasi 617 sampel.

Adapun kriteria inklusi dalam penelitian ini adalah sebagai berikut : (1). Klien yang didiagnosa mengalami cedera kepala dan memiliki data RR, SpO2, data mortality klien cedera kepala setelah 7 hari dilakukan perawatan. (2). Klien dengan rentang usia 20 65 tahun. Adapun kriteria eksklusi dalam penelitian ini adalah sebagai berikut : (1). Klien yang hamil, mengalami luka bakar serius dan intoksikasi (baik obat maupun alkohol). (2). Klien yang mengalami cedera serius lain yang dapat memperburuk kondisi klien (perdarahan intra abdominal, cardiac tamponade, fraktur multiple pada pelvis). (3). Klien yang mengalami penyakit PPOK.

Setiap data rekam medis klien dicatat kadar SpO2 yang terukur pertama kali saat di triage pada lembar observasional, kemudian diikuti selama 7 hari perawatan untuk dicatat kembali data mortalitynya (Arifin, 2008).

\section{HASIL PENELITIAN}

Tabel 1. Karakteristik Responden

\begin{tabular}{lcc}
\hline & $\mathbf{N}$ & $\%$ \\
\hline $\begin{array}{l}\text { Jenis Kelamin } \\
\text { Laki-laki }\end{array}$ & 112 & 74.7 \\
$\begin{array}{l}\text { Perempuan } \\
\text { Mekanisme Cedera }\end{array}$ & 38 & 25.3 \\
Kecelakaan & 139 & 92.7 \\
Jatuh & 11 & 7.3 \\
\hline Total & 150 & 100 \\
\hline
\end{tabular}

Berdasarkan Tabel 1 di atas, didapatkan hasil bahwa responden laki-laki jumlahnya lebih banyak (112 atau $74.7 \%$ ), dengan mekanisme cedera terbanyak didominasi oleh kecelakaan lalu lintas (139 atau 92.7\%).

Tabel 2. Data Oxygen Saturation Responden

\begin{tabular}{ccccc}
\hline Variabel & Rerata & Median & Min & Maks \\
\hline $\mathrm{SpO} 2$ & 83.818 & 87.5 & 50 & 99 \\
\hline
\end{tabular}

Berdasarkan Tabel 2 di atas, pada data SpO2 didapatkan median 87.5 dengan rerata 83.818 (50-99).Sehingga disimpulkan bahwa responden rata-rata mengalami hipoksia sedang.

Tabel 3. Hasil analisis Uji Mann-Whitney

\begin{tabular}{|c|c|c|c|c|c|}
\hline & \multirow{2}{*}{$\mathbf{n}$} & \multicolumn{2}{|c|}{ Mortality klien } & \multirow{2}{*}{$\begin{array}{c}\text { Median } \\
\text { (Min-Max) }\end{array}$} & \multirow{2}{*}{$p$} \\
\hline & & Mati & Hidup & & \\
\hline $\mathrm{SpO} 2$ & 150 & 47 & 103 & $87.5(50-99)$ & 0.000 \\
\hline
\end{tabular}

Berdasarkan hasil analisis uji Mann-Whitney diketahui bahwa terdapat hubungan yang bermakna antara mortality klien dalam 7 hari perawatan dengan kadar SpO2 $p$ value $=0.000(0.00<$ 0.05). 
Tabel 4. Hasil analisis regresi logistik SpO2

\begin{tabular}{cccc}
\hline & Variabel & Koefisien & $P$ \\
\hline \multirow{2}{*}{ Langkah 1 } & SpO2 & -0.304 & 0.000 \\
& Constanta & 24.569 & 0.000 \\
\hline
\end{tabular}

Berdasarkan hasil analisis uji multivariat regresi logistik, maka dapat diinterpretasikan :

1. Oxygen Saturation berpengaruh terhadap mortality klien cedera kepala dalam 7 hari perawatan.

2. Persamaan yang didapatkan adalah $\mathrm{y}=24.569+-0.304(\mathrm{SpO} 2)$.

3. Variabel SpO2 memiliki korelasi negative terhadap mortality klien cedera kepala dalam 7 hari perawatan (Dahlan, 2014).

Tabel 5. Nilai AUC SpO2

\begin{tabular}{ccc} 
& Nilai AUC & $\boldsymbol{p}$ Value Uji Hosmer and Lamesho \\
\hline $\mathrm{SpO} 2$ & 0.930 & 0.312 \\
\hline
\end{tabular}

Menurut Tabel 5. nilai $p$ value dari SpO2 $(0.312)>0.05$, sehingga disimpulkan bahwa persamaan $\mathrm{SpO} 2$ memiliki kalibrasi yang baik. Dilihat dari nilai AUC, dari SpO2 adalah 0.930 , sehingga disimpulkan bahwa persamaan $\mathrm{SpO} 2$ memiliki interpretasi sangat kuat terhadap mortality klien cedera kepala (Dahlan, 2014).

Tabel 6. Akurasi SpO2

\begin{tabular}{cccc}
\hline & \multicolumn{2}{c}{ Kemampuan Prediksi } & \multirow{2}{*}{$\%$} \\
\cline { 2 - 3 } & Hidup & Mati & \\
\cline { 2 - 3 } $\mathrm{SpO} 2$ & 98 & 5 & 95.1 \\
& 10 & 37 & 78.7 \\
\hline & Overall Percentage & & 90 \\
\hline
\end{tabular}

Berdasarkan hasil analisis akurasi SpO2, maka nilai sensitivity $=a /(a+c)=98 / 108=0.907$ $(90.7 \%)$, specificity $=d /(b+d)=37 / 42=0.881(88.1 \%)$, Positive Predictive Value $(P P V)=a /(a+b)=$ $98 / 103=0.951(95.1 \%)$, Negative Predictive Value $(N P V)=d /(c+d)=37 / 47=0.787(78.7 \%)$ (Dahlan, 2014).

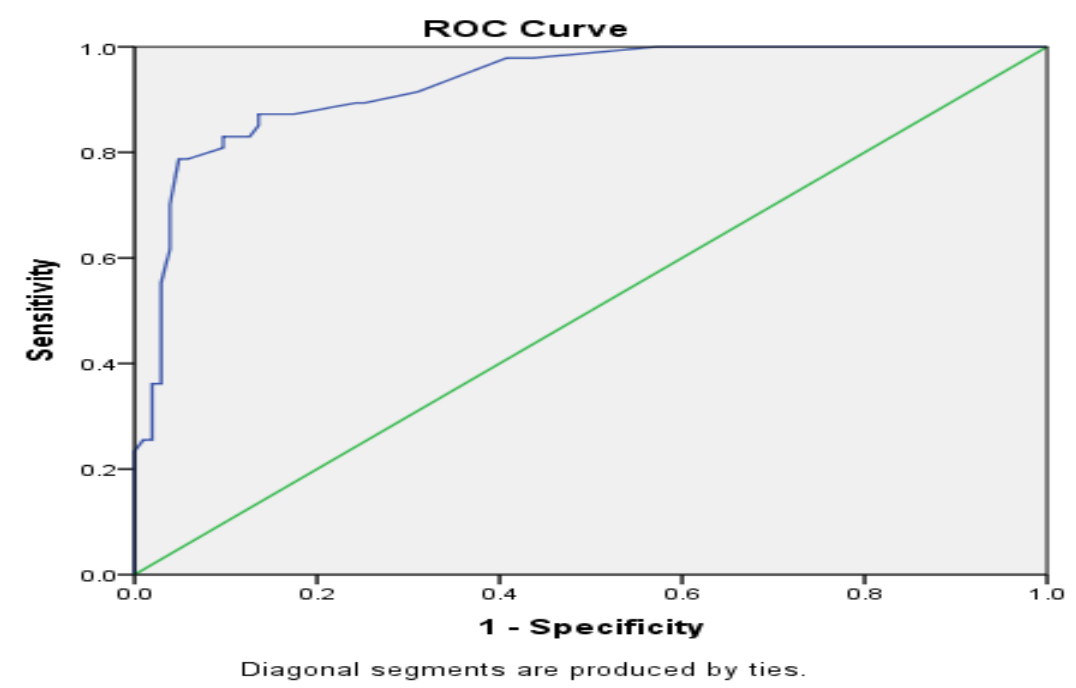

Gambar 1. Grafik ROC SpO2

Berdasarkan hasil analisis grafik ROC curve, SpO2 memiliki Area Under Curve (AUC) $=0.930$, dan kemampuan prediksi terhadap mortality klien cedera kepala sebesar 90\% (Dahlan, 2014). 


\section{PEMBAHASAN}

Berdasarkan hasil analisis Uji Regresi Logistik SpO2, memiliki sensitivity $=0.907$ $(90.7 \%)$, specificity $=0.881(88.1 \%)$, Positive Predictive Value (PPV) $=0.951$ (95.1\%), dan Negative Predictive Value (NPV) $=0.787$ (78.7\%) dengan kemampuan ketepatan prediksi sekitar 90\%. Berdasarkan hasil tersebut maka SpO2 dapat digunakan sebagai prediktor mortality yang baik pada klien cedera kepala. Hal tersebut didukung bukti bahwa variabel $\mathrm{SpO} 2$ memiliki korelasi signifikan terhadap mortality klien cedera kepala ( $p$ value $=0.000$ ). Oxygen Saturation memiliki negative correlation dengan mortality klien cedera kepala, artinya semakin meningkat jumlah $\mathrm{SpO} 2$ maka akan semakin menurun kejadian mortality klien cedera kepala.

Menurut hasil penelitian oleh Sittichanbuncha et al. (2015), oxygen saturation memiliki negatif korelasi dengan pre-hospital mortality. Semakin rendah oxygen saturation yang dimiliki klien maka semakin meningkat risiko kematian klien. Setiap kenaikan $1 \%$ oxygen saturation maka akan diikuti oleh penurunan risiko kematian sebesar $8 \%$. Hasil pemeriksaan oxygen saturation merupakan gambaran jumlah total oksigen yang berhasil dialirkan darah menuju jaringan dalam setiap menitnya (oxygen delivery). Secara tidak langsung, pengukuran oxygen saturation akan membantu mengetahui berapa jumlah oksigen yang masuk ke jaringan serebral. Maka dari itu, kejadian hipoksemia serebral dapat diprediksi melalui menurunkan nilai oxygen saturation, karena hasil pemeriksaan perifer oxygen saturation $\left(\mathrm{SpO}_{2}\right)$ di bawah $90 \%$ menunjukkan sebuah kondisi hipoksemia (Corwin, 2008; McMulan et al., 2013).

Kejadian hipoksemia serebral yang ditandai oleh adanya penurunan oxygen saturation dapat memicu terjadinya proses iskemik jaringan serebral (Soertidewi, 2012). Tubuh akan bereaksi secara otomatis untuk meningkatkan oxygen saturation dengan meningkatkan frekuensi pernafasan (Japardi, 2004 ; Sharf \& El-Gebali, 2013).

\section{DAFTAR PUSTAKA}

Bouzat, Pierre, Legrand, Robin, Gillois, Pierre, Ageron, François-Xavier, Brun, Julien, Savary, Dominique, Payen, JeanFrançois. (2015). Prediction of intrahospital mortality after severe trauma: which pre-hospital score is the most accurate? Injury. doi:
Namun, bila dengan cara meningkatkan frekuensi pernafasan belum mampu memperbaiki oxygen saturation, maka sel tubuh terutama cerebral akan mengalami kondisi infark.

Dengan adanya infark serebral akan berdampak pada kegagalan fungsi control pada organ-organ penting di dalam tubuh. Kondisi hipoksia jaringan cerebral yang melebihi 6 menit dapat menyebabkan outcome klien dengan trauma brain injury semakin memburuk dan berakhir dengan kematian.

Klien cedera kepala memerlukan suplai oksigen yang adekuat untuk memenuhi kebutuhan metabolisme otak. Oleh karena itu, pengukuran oxygen saturation merupakan salah satu monitoring evaluasi penting yang harus dilakukan pada klien dengan cedera kepala, karena oxygen saturation merupakan salah satu indikator penentu utama pada suplai oksigen dalam darah ke seluruh jaringan tubuh terutama jaringan serebral (McMulan et al., 2013).

Observasi oxygen saturation dilakukan untuk mencegah dan mengenali risiko terjadinya hipoksia jaringan terutama jaringan otak. Oxygen saturation juga dapat digunakan untuk mengevaluasi status pernafasan, terapi oksigen dan intervensi lainnya seperti suction, olah raga, dan fisioterapi (Brooker, 2005; Merenstein \& Gardner, 2002).

\section{KESIMPULAN DAN SARAN}

Hasil analisis uji regresi logistik $\mathrm{SpO} 2$, sensitivity $=0.907(90.7 \%)$, specificity $=0.881$ (88.1\%), Positive Predictive Value (PPV) = 0.951 (95.1\%), dan Negative Predictive Value $(\mathrm{NPV})=0.787(78.7 \%)$ dengan kemampuan ketepatan prediksi $=90 \%$. Oxygen Saturation (SpO2) merupakan prediktor yang baik (akurasi 90\%) terhadap mortality klien cedera kepala.

Penting dilakukan pemantauan oxygen saturation pada klien cedera kepala sejak di ruang triage IGD untuk mencegah terjadinya hipoksia serebral dan outcome yang buruk.

http://dx.doi.org/10.1016/i.injury.2015.10 .035

Brain Trauma Fondation. (2007). Managemen and Prognosis of Severe Traumatic Brain Injury. America,American Association of Neurological Surgeons, Joint Section on Neurotraumaand Critical Care. ISBN 0-9703144-0-X. 
Brooker, C. (2005). Ensiklopedi Keperawatan. (Andry Hartono, Brahm U. P, Dwi Widiarti:trans). Jakarta: EGC.

Corwin, M. (2008). Handbook of pathophysiology. Philadelphia: Lippinot William \& Wilkin.

Dahlan, S. (2014). Statistik untuk kedokteran dan kesehatan. Ed. 5. Jakarta: Salemba Medika

Davis, D. P., Meade, W., Sise, M. J., Kennedy, F., Simon, F., Tominaga, G., Steele, J., Coimbra, R. (2009). Both hypoxemia and extreme hyperoxemia may be detrimental in patients with severe traumatic brain injury. Journal of Neurotrauma. 26(12): 7.

Djojodibroto, D. (2007). Respirologi: Respirasi medicine. Jakarta: EGC

Japardi, I. (2004). Cedera kepala: memahami aspek-aspek penting dalam pengelolaan penderita cedera kepala. Jakarta: PT Bhuana IImu Populer.

Levine, J. M., Kumar, M. A., (2013). Traumatic brain injury. Neurocritical care society practice update.

Madikian A, Giza C. (2006). A Clinician's Guide to The Pathophysiology of Trauma Brain Injury. Indian Journal of Neurotrauma (IJNT). 3(1).9-1.

McMulan, J., Rodrigues, D., Hart, K. W., Lindsell, C. J., Voderschmidt, K., Wayne, B., Branson, R. (2013). Prevalence of prehospital hypoxemia and oxygen use in trauma patients. Military Medicine. 178(10): 5.

Merenstein, G. B., \& Gardner, S. L. (2002). Hanbook of nenonatal intensive care. Missouri: Mosby, Inc.

Minardi \& Crocco. (2009). Management of Treatment Brain Injury First Link in Chaine Survival. Mount Sinai Journal of Medicine. 78 (92) : 138-44. doi : 10.1002/msj.20105.
Rosyidi, C.H., Nurhidayat, S. (2009). Buku Ajar Perawatan Cidera Kepala dan Stroke. Yogyakarta: Ardana Media

Safrizal, S., Bachtiar, H. (2013). Hubungan nilai oxygen delivery dengan outcome rawatan klien cedera kepala sedang. Bagian IImu Bedah Fakultas Kedokteran. Padang: Universitas Andalas.

Sastrodiningrat, A. G. (2006). Memahami Faktor-Faktor yang Mempengaruhi Prognosa Cedera Kepala Berat. Majalah Kedokteran Nusantara. 39(3).

Sharf, M.S., El-Gebali, M.A. (2013). Correlation between glasgow coma scale and jugular venous oxygen saturation in severetraumatic brain injury. Egyptian Journal of Anaesthesia. 29, 267-272. http://dx.doi.org/10.1016/j.egja.2013.02. 008.

Sittichanbuncha, Y., Savatmongkorngul, S., Jawroongrit, P., Sawanyawisuth, K. (2015). Low oxygen saturation is associated with pre-hospital mortality among non-traumatic patient using emergency medical service: A national database of Thailand. Turkish Journal of Emergency Medicine. 30, 1-3. http://dx.doi.org/10.1016/j.tjem.2015.11. 003.

Soertidewi, L. (2012). Penatalaksanaan Kedaruratan Cedera Kranioserebral. Jakarta: FKUI

Wilensky, E. M., Gracias, V., Itkin, A., Hoffman, K., Bloom, S., Yang, W., Christian, S., LeRoux, PD. (2009). Brain tissue oxygen and outcome after severe traumatic brain injury: A Systematic Review. Critical Care Medecine Journal. 37(6), 2057-2063. 